\title{
"Mujique Marei": análise contextual e close reading*
}

Tatyana Kasatkina**

Resumo: "Mujique Marei” é um texto único de F. M. Dostoiévski, em que ao longo de quatro páginas o escritor apresenta de modo evidente ao leitor a sua estrutura da imagem (a estrutura que reproduz cada coisa do mundo da forma como ela se revela ao olhar profundo do artista), seu método criativo e sua maneira de discutir temas teológicos. 0 método de close reading e contextual permitem analisar e descrever a estrutura da imagem, o método criativo e as formas de discussões teológicas, assim como enxergar o sentido e o objetivo da presença de textos artísticos no Diário de um escritor e analisar os profundos significados do conto propriamente dito, que descrevem o processo de transformação do olhar, o surgimento do "olhar do artista", que é carregado de "lembranças trazidas da infância”, tão caras a Dostoiévski.
Аннотация: «Мужик Марей» - уникальный текст Ф.М. Достоевского, в котором на пространстве четырех страниц писатель наглядно представляет читателю свою структуру образа (воспроизводящую структуру всякой вещи в мире в том виде, в каком она открывается глубокому взгляду художника), свой творческий метод и свой способ богословствования. Метод пристального и контекстуального чтения позволяет нам проанализировать и описать эти структуру образа, творческий метод и способ богословствования, а также увидеть смысл и цель появления художественных текстов в составе «Дневника писателя» и проанализировать глубинные смыслы самого рассказа, описывающего процесс изменения взгляда, появления у автора «глаза художника», обеспеченный столь важным для Достоевского «воспоминанием, вынесенным из детства».

\section{Palavras-chave: Dostoiévski, "Mujique Marei"; estrutura da imagem; teoria da criação; teologia do escritor.}

Ключевые слова: Достоевский, «Мужик Марей», структура образа, теория творчества, богословие писателя 
* Artigo submetido em 02 de maio e aprovado em 09 de maio de 2018. Pesquisa realizada no Instituto de Literatura Mundial Górki (IMLI), da Academia Russa de Ciência, com financiamento do Fundo Científico Russo (RNF, projeto no 17-18-01432). Исследование выполнено в Институте мировой литературы им. А.М. Горького РАН за счет гранта Российского научного фонда (РНФ, проект № 17-18-01432)

** Doutora em Letras, presidente da comissão de estudo do legado artístico de F. M. Dostoiévski do Conselho Científico História da Cultura Mundial da Academia Russa de Ciência, diretora do Departamento de Teoria Literária do IMLI. E-mail: t-kasatkina@yandex.ru

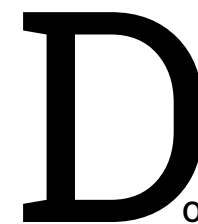

ostoiévski nos atrai como um grande filósofo, um grande teólogo, um grande cristão. Mas não podemos ouvi-lo nem como filósofo nem como teólogo sem compreendê-lo como artista, sem assimilar sua linguagem artística. A melhor forma de estudar essa linguagem é pelos textos artísticos presentes no Diário de um escritor, na medida em que aqui, lado a lado com artigos de publicística, Dostoiévski às vezes chega bem próximo da manifestação daquilo que é o ápice de sua expressão em textos artísticos.

No capítulo que antecede o mais curto entre os textos mais significativos de Dostoiévski, "Mujique Marei", o escritor propõe diretamente uma estrutura da imagem do homem da maneira como ele a vê e a representa em seus textos artísticos:

No homem russo de origem humilde é preciso saber distinguir a sua beleza das camadas de barbárie. Nosso povo, pelas circunstâncias de quase toda a história russa, se dedicou tanto à devassidão e foi tão corrompido, tentado e constantemente atormentado que chega a ser surpreendente que ele tenha sobrevivido preservando sua imagem humana, e ainda mais sua beleza. Mas ele preservou também a beleza de sua imagem. ${ }^{1}$

Vemos aqui uma imagem que não é nem dupla, mas tripla. ${ }^{2}$ Se sairmos da superfície para o fundo, ela pode ser descrita da seguinte forma: camadas de barbárie - imagem humana - beleza dessa imagem.

É característico que "Mujique Marei" seja apresentado pelo autor na qualidade de conclusão desse raciocínio antecedente (e, em certo sentido, como substituição a ele: como texto em que é dito exatamente o mesmo e muito mais). Isso nos permite formular o objetivo geral do aparecimento de textos artísti-

${ }^{1}$ DOSTOIÉVSKI, 1981, vol. 22, p. 43.

${ }^{2}$ Cf. KASATKINA, 2015. 
cos no Diário de um escritor. Eles são apresentados por Dostoiévski no momento em que a profundidade da generalização e clarividência comunicadas tornam praticamente impossível sua reprodução na forma de raciocínio, de maneira discursiva. É justamente nesse momento que Dostoiévski passa à representação do concreto, à imagem, ao "caso isolado", atualizando a arte como forma de transmissão direta da experiência, da sensação, do sentimento, sem passar pelas etapas do conhecimento e compreensão, incontornáveis para o texto discursivo, voltado à razão e não ao coração. Dostoiévski, ao chegar às mais elevadas ideias, as oferece ao leitor de modo que ele possa assimilá-las sem raciocínio; de forma que a ideia possa germinar nele como uma semente guardada na cápsula do enredo, e brotar no momento adequado.

Eis como ele realiza essa passagem em "Mujique Marei":

Mas acho muito entediante ler sobre todas essas professions de foi, e por isso contarei uma anedota, aliás, não é nem uma anedota, apenas uma lembrança distante que, por algum motivo, gostaria muito de contar justamente aqui $e$ agora, na conclusão de nosso tratado sobre o povo. ${ }^{3}$

Apesar da expressão direta da vontade do autor ("contar justamente aqui e agora"), "Mujique Marei" é constantemente editado, lido e interpretado separadamente do Diário de um escritor, arrancado de seu contexto. E isso, sem dúvida, dificulta sua compreensão, na medida em que o texto artístico é importante não apenas como conclusão do raciocínio e sua tradução para um campo que ele geralmente não alcança, mas o raciocínio anterior ao texto também é extremamente importante para o autor, pois apresenta a perspectiva sob a qual o texto artístico deve ser apreendido, coloca o leitor no mesmo ponto em que o autor, oferece certas chaves para o texto.

De forma extremamente significativa e estruturalmente impecável, Dostoiévski começa seu conto sobre "apenas uma lembrança distante", embora para o leitor, à primeira vista, isso pareça um tropeço do autor, uma incoerência e até certo descuido: "Naquela época, eu tinha apenas nove anos de idade...

${ }^{3}$ DOSTOIÉVSKI, 2015, p. 173. Grifos da autora. (N. da T.) 
não, melhor começar com quando eu tinha 29 anos de idade". ${ }^{4}$ Dostoiévski nos faz ver claramente que ele intencionalmente coloca uma recordação no centro de outra, combinando-as.

Compreendemos que tratam-se de dois acontecimentos, mas eles compõem uma recordação, pois um dos acontecimentos (o primeiro e mais importante) está apenas dentro de outro, mais tardio em termos temporais, mas sem o qual não haveria necessidade de recordar o primeiro. O primeiro acontecimento, à primeira vista, não é tão importante (por isso, inclusive, havia sido esquecido), mas adquire todo seu significado apenas ao se tornar o centro energético do segundo acontecimento. O primeiro acontecimento transfigura o segundo, mas o segundo é o único lugar em que ele foi exigido, e por isso ele pode renascer, manifestar-se, receber uma interpretação e revelar toda sua qualidade transformadora. O primeiro acontecimento despertou na memória de forma não consciente, apenas em termos narrativos, como uma obra de arte sentida, mas ainda não compreendida em toda sua profundidade, e foi percebido no momento em que se tornou vitalmente importante.

Precisamente aqui, Dostoiévski mostra de modo bastante "tecnológico" por que são tão importantes as lembranças da infância (as quais podemos esquecer completamente por um tempo), e como funciona aquilo que é descrito em Os irmãos Karamázov, em um olhar superficial, como certa afirmação sentimental e, por isso, duvidosa: "Muitos vos falam de vossa educação, mas uma lembrança maravilhosa, sagrada, conservada desde a infância, pode ser a melhor educação. Se o homem traz consigo muitas dessas lembranças para a sua vida, está salvo pelo resto da existência. Mesmo que guardemos apenas uma boa lembrança no coração, algum dia só isto já nos poderá servir como salvação". ${ }^{5}$

Dois acontecimentos se combinam em uma recordação que, por sua vez, possui uma ação transformadora em relação a outros textos desse capítulo de $O$ diário de um escritor, assim

${ }^{4}$ Idem.

${ }^{5}$ DOSTOIÉVSKI, 2008, p. 996. 
como dentro da recordação do primeiro acontecimento para o segundo. Surge uma estrutura textual tripartida, análoga à estrutura tripartida da imagem do homem proposta por Dostoiévski: texto publicístico - segunda recordação - primeira recordação.

Isso se inicia exteriormente, a segunda "recordação" surge com a descrição da "camada de imundice": forçados se divertindo na Páscoa, sujeitos cuja imagem humana o Dostoiévski daquele tempo é inicialmente incapaz de perscrutar.

Antes de passar à recordação propriamente dita, observamos que mais à frente no texto será ressaltado de maneira especial que o conto é conduzido não pela pessoa de um narrador ou herói, mas justamente pela "minha" pessoa, a pessoa de Dostoiévski, o autor do Diário de um escritor. Aqui ele se distancia intencionalmente de outro texto sobre as galés, onde 0 narrador é ficcional, assinalando com isso a veracidade nesse caso:

Talvez tenham observado que até hoje não publiquei quase nada sobre minha vida nas galés, escrevi Recordações da casa dos mortos quinze anos atrás, usando um personagem ficcional, um criminoso que teria matado a esposa. A propósito, acrescento como detalhe, desde então muitos ainda pensam e afirmam que fui preso pelo assassinato de minha esposa. ${ }^{6}$

Mas, ao mesmo tempo, com essa referência ele evidentemente introduz "Mujique Marei" em relação contextual com Recordações da Casa dos Mortos. A partir desse momento, eles devem ser analisados como contexto próximo um do outro, e isso é fundamentado inclusive porque, na primeira parte de Recordações, o Natal é viva e detalhadamente analisado e profundamente sentido (como processo de surgimento do corpo único da humanidade), mas a Páscoa, que deveria ser o centro da segunda parte, é como que cortada, uma espécie de espaço vazio, um buraco em torno do qual se constrói o texto da segunda parte. Ali Dostoiévski, enfim, escreveu sobre a Páscoa, como ela era concebida por ele nas galés. Com sua insistência

${ }^{6}$ DOSTOIÉVSKI, 2015, p. 175. 
na realidade e no fato de a narrativa ser feita por ele mesmo, ressaltou que o mistério da Páscoa, o mistério da possível ressurreição e transfiguração do homem, que sempre está presente e inextirpável dele, é o que de mais importante ele trouxe das galés. Contudo, ao mencionar aqui as Recordações da casa dos mortos, Dostoiévski ao mesmo tempo introduz em seu pequeno grande conto também o contexto do Natal, extremamente importante nele.

Assim, voltemo-nos à segunda recordação:

"Já era o segundo dia do 'feriado' na prisão, os forçados não tinham sido levados para o trabalho, havia muitos bêbados, xingamentos, a cada minuto começavam brigas em todos os cantos. Canções horríveis, baixas, maidanes com jogos de azar debaixo das tarimbas, uns presos, por algum excesso particular, espancados quase até a morte conforme sentença dos próprios camaradas e cobertos com casacos nas tarimbas até que voltassem à consciência e despertassem; algumas vezes chegavam a mostrar facas: tudo isso, nos dois dias de feriado, me atormentou até me deixar doente. De fato, nunca pude suportar sem repulsa uma farra popular regada a álcool, e especialmente aqui, neste lugar. Nesses dias, a chefia da prisão nem vinha dar uma olhada, não passava em revista, não procurava vinho, entendia que era preciso permitir que mesmo esses miseráveis se divertissem uma vez no ano, ou então poderia ser pior. Enfim, meu coração ardia de raiva. Encontrei o polonês M...tski, um dos presos políticos; ele me olhou de modo soturno, seus olhos brilharam e os lábios começaram a tremer:

'Je hais ces brigands!', rangeu ele a meia voz e passou direto. Retornei à caserna, apesar de ter saído feito um louco de lá apenas quinze minutos antes, quando seis homens saudáveis se atiraram de uma vez no bêbado tártaro Gazin para acalmá-lo e começaram a bater nele..."7

Aqui a ordem dos eventos é muito importante: a raiva arde no coração do narrador, suscitada pelo fato de que naquele momento ele não era capaz de ver nas pessoas que o cercavam nada além da excessiva camada de imundície, que ele toma naquele instante por essência do homem; é como se ele firmasse o olhar na terra que cobre o caixão sem supor houvesse

${ }^{7}$ Ibidem, p. 173-4. 
vida ali, ou melhor, é como se ele criasse esse caixão com seu olhar, como se em resposta a essa raiva de fora ressoassem palavras de ódio que sustentam que a imundície é tudo o que existe nesses "bandidos"; um ódio mortal, que deseja a destruição daquilo que odeia tão furiosamente.

Notamos que essas palavras não soam (ou não têm chance de serem compreendidas) até que a raiva surja internamente. Nosso interior condiciona o mundo ao nosso redor, é o que Dostoiévski parece sublinhar. Mas o mundo ao redor nos permite ver a monstruosidade daquilo que é internamente percebido como justa indignação. $O$ mundo nos oferece uma ligação inversa clara e adequada - desde que estejamos dispostos a percebê-la. Podemos conhecer a nós mesmos apenas observando a forma como os nossos sentimentos se refletem no exterior. E depois de vê-los em sua forma verdadeira, teremos a chance e modificá-los.

Assim, o autor retorna à caserna. Ele está deitado e se entrega a lembranças, aparentemente numa tentativa de fuga daquela realidade miserável, mas de fato inicia o processo de ligação dela com a primeira lembrança e sua ulterior elaboração. E como que de passagem nos comunica como ele trabalha com os eventos da realidade para criar sua imagem verdadeira:

Essas lembranças sugiram por si mesmas, eu raramente as suscitava por vontade própria. Começava com algum ponto, um traço às vezes imperceptível, e então, pouco a pouco, tornava-se um quadro completo, uma impressão forte e integral. Eu analisava essas impressões, acrescentava novos traços àquilo que fora há muito vivido e, o principal, corrigia, corrigia sem parar: nisso consistia minha diversão. ${ }^{8}$

Do detalhe surge um quadro completo, que é uma impressão forte e integral. Essa passagem, aliás, indica uma forma de análise adequada ao modo de construção do texto de Dostoiévski: é justamente o detalhe, o traço quase imperceptível, que pode e deve ser seu ponto de partida, e seguindo as aventuras desse detalhe nós seremos capazes de reproduzir a linha de sentidos existentes no texto do escritor. A análise comple-

${ }^{8}$ Ibidem, p. 175. 
ta pode começar de qualquer ponto, de qualquer "traço imperceptível", pois tudo no texto é entrelaçado e urdido, e não simplesmente entrelaçado, mas com esse "traço imperceptível" é tanto engendrado nele como se transforma a partir dele.

A impressão forte e integral está sujeita à análise do autor, ou seja, nela se oculta seu sentido profundo, são revelados "os fins e os princípios", os quais não são mostrados ao leitor naquilo que é "essencial do visível e cotidiano" se colocarmos da maneira como ele flui, mas que podem ser revelados pelo artista "que tem olhos"; depois, por meio da atribuição de novos traços, esse pensamento, esse fundamento, essa base do universo, ${ }^{9}$ inicialmente observados apenas pelo autor, cada vez mais se manifestam no quadro total: por isso o próprio processo é chamado pelo autor de correção. Ao modificar os traços iniciais inerentes à lembrança, que não contribuíam para o surgimento do sentido do acontecimento e que, consequentemente, eram fortuitos, e ao atribuir novos sentidos do acontecimento que se revelam, o autor não altera, não distorce, mas corrige o quadro, aclara-o, permitindo a descoberta do sentido de forma maximamente clara, de modo que "o leitor, ao ler o romance, compreenda exatamente o pensamento do escritor, da maneira como ele o compreende ao criar a sua obra".$^{10}$

\footnotetext{
${ }^{9}$ E como base do universo, como local dos "fins e princípios", o herói de Dostoiévski, como lembramos no romance Os irmãos Karamázov, descreve a Bíblia: "Que livro são essas Sagradas Escrituras, que milagre e que força dá ao homem! É como se fosse uma estátua do mundo e do homem e dos caracteres humanos, e tudo isso nomeado e indicado para todo 0 sempre. E quantos mistérios resolvidos e revelados" (DOSTOIÉVSKI, 2008, p. 400). Apontamos também para o fato de que os "fins e princípios", que se encontram além dos limites do "essencial do visível e cotidiano", é uma clara, embora alterada, citação: assim Cristo nomeia a si mesmo quatro vezes no Livro da Revelação de João: "Eu sou o Alfa e o Ômega, o princípio e o fim, diz o Senhor, que é, e que era, e que há de vir, o Todo-Poderoso (1, 8); "Eu sou o Alfa e o Ômega, o primeiro e o último" (1, 10); "Eu sou o Alfa e o Ômega, o princípio e o fim" (21, 6); "Eu sou o Alfa e o Ômega, o princípio e o fim, o primeiro e o último" $(22,13)$. Eis o centro profundo, a imagem interna recuperada pelo escritor que "possui olhos" em cada acontecimento da vida cotidiana.

${ }^{10}$ Essa rica capacidade do leitor, reestabelecida pela realidade, de compreender inteiramente a intenção do autor ou, como diríamos hoje em dia, de interpretar de forma absolutamente adequada, é para Dostoiévski o único critério verdadeiro da arte: "Como reconhecer o caráter artístico em uma obra? Enxergar a harmonia, se possível completa, entre a ideia artística e a forma em que ela é apresentada. Digamos de maneira mais clara: o caráter artístico no romancista, por exemplo, é a capacidade de expressar seu pensamento em personagens e imagens de forma tão clara que o leitor, ao ler o romance, compreende o pensamento do
} 
É interessante que nessa enunciação sobre a natureza da criação, cujas palavras-chave tomo emprestado aqui, Dostoiévski consolida afinidades de princípios da estrutura da imagem da realidade e da estrutura da imagem da grande obra de arte:

Com efeito, investigue algum fato da vida real, mesmo que não seja o mais incrível à primeira vista, e se o senhor tiver olhos e forças, descobrirá nele uma profundidade que não existe em Shakespeare. Mas a questão consiste no seguinte: aos olhos de quem e com as forças de quem? Não apenas para criar e escrever obras literárias, mas para simplesmente notar o fato é preciso também ser como que um artista. Para alguns observadores, todos os acontecimentos da vida se desenrolam na mais comovente simplicidade e são tão óbvios que não há sobre o que pensar, não há sequer algo que mereça ser visto [...] Contudo, é claro que nunca será possível esgotar todo o acontecimento, nem alcançar seu principio e seu fim. Conhecemos apenas o essencial do visível e cotidiano, e ainda assim só de vista; já os fins e os princípios ainda representam para o ser humano algo fantástico". ${ }^{.1}$

Por isso, os fatos da vida real não requerem uma reelaboração radical, mas apenas sua correção, e isso está longe de fazer de Dostoiévski um documentarista, e não destitui a integridade da obra de arte, que poderia parecer ser apresentada como mosaico de tais fatos "corrigidos". Mas é preciso observar de passagem que a indicação dos fatos-protótipos no comentário aos textos deve ser acompanhada da análise das "correções" feitas pelo artista, do contrário o comentário apenas "espalhará" a obra de arte e desorientará o leitor, desviando radicalmente sua atenção da intenção do autor.

Dessa vez, na terrível caserna das galés, Dostoiévski se recorda de um encontro de sua infância com um "homem russo de origem simples". Os vinte anos entre as lembranças são tirados como uma casca, como uma camada protetora, devolvendo ao autor a pureza infantil e a amplitude do mundo. Para ver o interior do outro, ele precisa antes de tudo recuperar o acesso ao

escritor exatamente da maneira como ele mesmo o compreendeu ao criar sua obra" (DOSTOIÉVSKI, 1978, p. 80).

${ }^{11}$ DOSTOIÉVSKI, 2017, p. 353. 
seu próprio interior, a si mesmo, que está encoberto pela casca da camada de imundice formada ao longo de vinte anos. Pois há coisas que não vemos não pelo fato de que elas estão ocultas por uma camada de imundice; há coisas que não vemos devido à nossa própria camada de imundice, que encobre nossa visão e bloqueia nossa capacidade de percepção. $O$ autor precisa retornar a si mesmo até o momento (ou no momento mesmo) do encontro com a terrível e absoluta morte, que distorce radicalmente a perspectiva da visão humana; a morte que é a fonte de toda imundície e da qual tentamos nos esconder na casca do eu, ainda que o eu seja uma armadilha preparada pela morte para nós; a morte que se manifesta no conto pela imagem do lobo. Mas ainda voltaremos a isso.

O garoto brinca na natureza e ouve a pouca distância um mujique que "lavrava firmemente no monte; o cavalo seguia com dificuldade e, de quando em quando, chegava até mim seu grito: 'Eia, eia!"'12. Se formos à propriedade Darovóie, que pertenceu à família de Dostoiévski, veremos que não há onde "lavrar firmemente no monte". O local é plano. $E$ isso pode ser visto até mesmo pela descrição da região em "Mujique Marei". Sobre o que Dostoiévski começa a falar ao corrigir sua recordação? Ele fala de um movimento ascendente que não é físico, mas espiritual. A lavoura da terra é uma imagem do trabalho sobre si mesmo, do trabalho espiritual de elevação, da lavoura do próprio solo, sobre o qual deve cair e germinar o fruto da semente do Senhor, que é a semente da liberdade, como veremos adiante. Esse sentido é introduzido por Dostoiévski na imagem do mujique que lavra, corrigindo sua recordação.

De repente, o garoto que brincava tranquilamente ouve um grito: "É um lobo!". Ele sai correndo, "fora de si pelo susto", da mesma forma que, adulto, ele corre "feito um louco" da caserna ao ver os mujiques espancarem o tártaro bêbado, mas na primeira recordação, que se revela no coração da segunda e que está ligada a ela por termos de sinalização, ele "corre para a clareira na direção do mujique que lavrava". ${ }^{13}$

${ }_{12}$ DOSTOIÉVSKI, 2015, p. 176.

${ }^{13}$ Ibidem, p. 177. 
Aqui, na recordação da infância, o mujique não é fonte de ameaça monstruosa, mas uma figura protetora e salvadora. Não é aquele de quem ele corre, mas na direção de quem corre. "Nosso mujique". Dostoiévski apresenta de maneira surpreendente um claro "ritmo textual" em relação a essa situação. O garoto corre do lobo, mas só volta a si e se sente totalmente seguro quando em sua direção se atira "nosso cachorro Lobinho". ${ }^{14} \mathrm{O}$ defensor está oculto sob aquele que parece a fonte do perigo, pois quem leva o nome de lobo é um cachorro. Por isso é preciso buscar proteção não contra ele, mas nele. Profundamente nele...

Mas por que justamente o lobo assusta tão terrivelmente o garoto e se torna o símbolo do encontro com a morte, o símbolo do medo da morte? O lobo para a criança não é um rival, um inimigo, mas precisamente o mais puro pavor, pois a criança é apenas alimento para o lobo. "Chega um lobo cinzento e agarra pela lateral", essa é uma canção de ninar sobre a morte. $O$ conflito com o lobo é a materialização total do pequeno homem. Essa sensação de ser quase $o$ alimento ressurge no autor diante dos forçados. "Bandido", aquele que consegue seu sustento tirando a vida do homem por uma migalha. Nesse sentido, é significativo o relato recordado por Dostoiévski nas galés e registrado no "Caderno siberiano" do bandido que passava sermão em seu filho, que havia esfaqueado um mujique e tirado dele apenas uma cebola: "Idiota! Uma cebola, um copeque [...] Cem almas, cem cebolas, aí sim tem um rublo". O outro traz a morte - é isso o que Dostoiévski sente e de que pretende fugir na Grande Festa da Ressurreição.

O mujique Marei é aquele que salva a criança do medo da morte, mas para o adulto ele transforma a sensação de morte em seu contrário: o outro traz a vida e protege contra a morte.

São extremamente importantes as palavras que Marei usa para acalmar o garoto.

${ }^{14}$ Ibidem, p. 178. 
- Mas o que é isso, que lobo? Foi impressão sua, veja! Que lobo pode haver aqui? - murmurou tentando me dar alento.Mas eu tremia todo e agarrava ainda mais forte seu casaco, devia estar muito pálido. Ele me olhou como um sorriso intranquilo, parecia alarmado e preocupado comigo.

- Se assustou mesmo, hein! - balançou a cabeça. - Já chega, querido. Ei, rapazinho!

Ele estendeu a mão e, de repente, afagou minha bochecha. - Bem, já chega, que Cristo esteja contigo, faça o sinal da cruz.

Mas eu não fiz, os cantos dos meus lábios tremiam e, parece, isso o impressionou muito. Devagar, estendeu o dedo gordo, sujo de terra e com uma unha preta, e tocou suavemente meus lábios agitados.

- Ei, calma - ele sorriu para mim com um sorriso maternal e demorado. - Meu Deus, o que é isso, se acalme! Enfim, entendi que não havia nenhum lobo [...] $]^{15}$

Inicialmente, Marei diz ao garoto (que ele chama de "querido" e "rapazinho", palavras que criam dentro da narrativa uma atmosfera de nascimento da criança, amparada pela estranha e repetitiva exclamação "Ei"), ${ }^{16}$ que Cristo está com ele, e que ele deve fazer o sinal da cruz. Mas isso ainda não acalma o garoto. Em seguida, o sorriso de Marei, que antes era "intranquilo", se torna "maternal", e dizendo frases aparentemente incompreensíveis, compostas de interjeições, na verdade se dirige ao garoto com a palavra "Senhor". Depois disso ele, enfim, compreende que não existe nenhum lobo. Estranhamente, Dostoiévski mostra aqui o processo de nascimento de Deus no homem, da sensação em si mesmo da imagem divina, independente da morte, que é vencida por Cristo. Pois se Cristo está com você, isso ainda não diz nada sobre sua imortalidade. Mas se Cristo está em você, a morte não existe. O outro se torna uma extensão na qual Deus pode nascer em você. No pequeno Dostoiévski, Deus nasce no olhar do mujique Marei. O Dostoiévski adulto compreende que ele pode dirigir ao outro esse olhar que faz nascer.

\footnotetext{
15 Ibidem, p. 177-8.

${ }^{16}$ Aqui é preciso ressaltar que a palavra empregada por Dostoiévski, ródnyi (vertido como "querido"), designa uma forma de tratamento carinhosa, e que sua raiz é a mesma do verbo rodít(dar à luz). (N. da T.)
} 
Em "Mujique Marei" é muito importante o fato de que o lobo na realidade não existe. $\mathrm{O}$ grito do lobo é ouvido apenas pelo garoto. Já o cachorro Lobinho existe. O lobo que deixou o garoto fora de si de susto é apenas uma miragem, um erro de percepção, uma ameaça trazida por rumores e relatos de outrem. o cachorro Lobinho, que o deixou "completamente animado" (não apenas voltou a si, mas como que despertou internamente), é uma realidade direta e indubitável.

Por isso, o olhar de Dostoiévski se altera radicalmente:

Então, quando saí da tarimba e olhei ao redor, lembro-me de sentir subitamente que podia olhar para aqueles infelizes de uma forma completamente diferente, e que, de repente, como que por um milagre, todo o ódio e raiva tinham desaparecido do meu coração. Caminhei, olhando com atenção no rosto daqueles que encontrava. Esse mujique difamado e de cabeça raspada, com marcas no rosto, bêbado, bradando sua rouca e embriagada canção, pode ser aquele mesmo Marei: com efeito, eu não consigo perscrutar seu coração. Naquela mesma noite, encontrei-me outra vez com M...tski. Infeliz! Nele não poderia haver quaisquer reminiscências de nenhum Marei, ele não via nada nas pessoas, além de 'Je hais ces brigands!'. Não, naquela época esses poloneses sofreram mais do que os nossos!" ${ }^{17}$

Assim se reestabelece para Dostoiévski a imagem humana nos forçados estigmatizados. Graças à sua recordação de infância, ele aprende a ver através da camada de imundície, ele adquire o "olhar do artista" que penetra fundo as coisas. Mas, vejamos, ele não se orgulha disso diante do preso polonês, mas se compadece dele. Dostoiévski compreende que aquilo que lhe foi concedido naquele instante, aquilo que abriu seus olhos, não é um mérito, mas um privilégio recebido graças à recordação da infância. Um privilégio que ele agora tem a obrigação de compartilhar com os demais, com qualquer membro da humanidade (o artista, em certo sentido, se torna a visão recuperada de toda a humanidade, ele é o órgão da humanidade toda, que deve cumprir sua obrigação), e especialmente com aqueles que não tiveram nenhum Marei na infância.

Não apenas a imagem humana se reestabelece, mas também sua beleza. $\mathrm{E}$ a beleza da imagem é sempre feminina em

${ }^{17}$ Ibidem, p. 180. 
Dostoiévski. "A imagem humana" do mujique lembra o Deus-Pai como ele às vezes é representado: "um mujique de uns cinquenta anos, corpulento, bastante alto, com muitos fios grisalhos e sua vasta barba castanho-escura". ${ }^{18}$ Mas o nome do mujique não existe ("não sei se existe tal nome", ${ }^{19}$ escreve Dostoiévski), ou seja, não existe a forma masculina na língua russa (nas línguas europeias ele é bastante comum), pois é o nome feminino "Maria". E Dostoiévski se lembrará nas galés de sua ternura feminina, maternal.

[...] recordei-me daquele sorriso maternal e carinhoso do pobre mujique camponês, de seu sinal da cruz, de seu aceno com a cabeça: 'Se assustou mesmo, hein, rapazinho!'. Mas em especial daquele seu dedo gordo, sujo de terra, com o qual ele suavemente e com tímida ternura tocou meus lábios trêmulos. É claro que qualquer um confortaria uma criança, mas naquele encontro solitário aconteceu algo inteiramente diverso, e ainda que eu fosse seu próprio filho, ele não poderia me dirigir um olhar que irradiasse amor mais puro; mas o que o levou a fazer isso? Ele era nosso servo, e eu o filho de seu senhor, ninguém ficaria sabendo como ele me afagou e nem o recompensaria por isso. Será que ele amava tanto assim as crianças pequenas? Existem pessoas desse tipo. 0 encontro foi solitário, no campo vazio, e apenas Deus, quiçá, viu lá de cima que sentimento humano profundo e esclarecido e que ternura delicada, quase feminina, pode existir no coração de um mujique russo bruto, bestialmente ignorante, que ainda não esperava ou mesmo imaginava sua liberdade. ${ }^{20}$

"O mujique forte e corpulento com vasta barba", no fundo de sua imagem, onde sua beleza se revela, é Mãe que cuida, protege e é infinitamente misericordiosa ${ }^{21}$ (o dedo de que o au-

\footnotetext{
${ }_{18}$ É praticamente assim que Deus-Pai será representado no mural de teto na Fortaleza de Milão (Castello Sforzesco), na capela de Herzog (século XV).

${ }^{19}$ Ibidem, p. 177. Justamente devido à "dúvida" do autor, os pesquisadores seguem um caminho evidentemente falso, explicando o nome "Marei" como variante popular de "Mário" e realizando, com base nisso, um longo embate do "nosso mujique" com o chefe militar romano. Cf.: VETLÓVSKAIA, 2018, n. 1. Da existência do nome Marei, Dostoiévski não duvidava, mas justamente aqui era necessário que o leitor sentisse toda a inverossimilhança do acontecido. Esta é outra "correção" intencional, uma vez que, segundo a recordação de A. M. Dostoiévskaia, "Marei" se chamava Mark (Cf. DOSTOIÉVSKI, 1981, p. 344).

${ }^{20}$ Ibidem, p. 179-80.

${ }^{21}$ Assim também, o Deus-Pai representado na Fortaleza de Milão, debaixo da vasta barba,
} 
tor se recorda especialmente, sujo de terra e gordo [ou seja, de carnalidade acentuada: de fato Maria é a origem do corpo de Deus], com o qual ele comunga a terra com o garoto assustado, em combinação com o nome, reproduz uma imagem muito significativa para Dostoiévski: "Mãe de Deus - Mãe Terra").

Assim a beleza salva o mundo, se formos capazes de desenterrar a imagem humana da camada de imundície e enxergar a imagem humana através da camada de imundície dos outros. Depois, das profundezas de sua imagem humana sólida, corpulenta, forte e protegida, liberar sua beleza indefesa (pois não se protege), impensadamente dispensada, infinitamente misericordiosa.

Mas Dostoiévski não apenas faz uso do nome da Mãe de Deus para a criação e revelação de sentidos de seu próprio texto artístico. Ele também, ao mesmo tempo, se utiliza de seu texto para fazer a exegese do texto bíblico. E se em primeiro lugar há a ação do escritor, em segundo há a ação do teólogo. Esse é o princípio geral da criação de suas obras: Dostoiévski, ao "unificar" seu texto com o texto bíblico ou com a história cristã por citações e alusões, em seguida, no próprio "corpo" do texto artístico, em seu enredo e estrutura revela sentidos inesperados da fonte, comunica algo não apenas sobre o personagem, mas também sobre Cristo. Em outras palavras, ele inicialmente usa a alusão para comunicar sentidos complementares ao texto, no qual a alusão é introduzida, em seguida, para comunicar alguns sentidos complementares sobre o texto ao qual a alusão se refere. Ao combinar o texto bíblico ou o enredo com aquilo que é concretamente narrado por ele em certo momento da história, ele retira o estranhamento de nossa percepção da história bíblica, é como se ele nos lançasse em seu abismo, fizesse dela não uma abstração teológica, mas uma novidade, um "escândalo" e uma "loucura". ${ }^{22}$

Assim, voltando à ultima citação apresentada, tentaremos compreender agora não o que a imagem de Maria oferece para a compreensão da imagem de Marei, mas o que a imagem de

revela um delicado peito desnudo feminino. De modo geral, a representação do "Pai que alimenta" não era muito frequente, mas estava longe de ser excepcional na arte cristã.

${ }^{22}$ Cf. Coríntios, 1, 23. 
Marei oferece para a compreensão de Maria. Como Dostoiévski, por meio da confrontação dessas imagens, implode nossa rígida e falsa representação da Mãe de Deus. Pelo encontro do mujique animalesco e ignorante com o filho de seu senhor, pelo serviço humilde e amoroso do subalterno, mas ainda o mais forte, prestado ao seu frágil e impotente superior, Dostoiévski revela a distância que separa o homem - Marei - de Deus e de seu filho. Ele nos obriga a sentir essa irrepresentável distância entre aquilo que para nós é muito mais fácil imaginar e compreender. A infinita distância e toda a firmeza e liberdade de Maria, que decidiu e desejou superar essa distância (ou menosprezá-la, como Marei, num impulso de amor e cuidado) e tomar como "próprio filho", com a ternura maternal daquele que, enfim, é para ela mais do que o "filho do senhor", seu Deus (e aqui o gesto de Marei atua de maneira absolutamente particular, com os dedos sujos de terra tocando os lábios do garoto: assim a Mãe apresenta a terra à Prole que não pertence à terra: apresenta-a à sua desgraça e pobreza, mas também àquilo que proporciona seu crescimento. Cristo irá repousar duas vezes no ventre da terra: no Natal e no Sepultamento, a terra dá a luz a ele nesta e na outra vida.

Mas sua abnegada aceitação e cuidado maternal e terno com o Superior é o caminho não apenas para a sua liberdade, mas para toda a humanidade (assim como a iluminada ternura de Marei é para Deus [e para Dostoiévski] prova de sua prontidão para a liberdade de todo o povo russo). A partir de então, Deus vê nas profundezas de cada homem aquela que respondeu ao seu chamado e com desvelo tomou para si a tutela de sua fragilidade infantil. Da mesma forma, nas profundezas de cada forçado, Dostoiévski vê Marei.

A beleza de qualquer homem se torna indestrutível para Deus, pois foi cuidada e protegida pela Mãe de Deus. No universo da interpretação teológica, podemos ler mais a fundo a citação apresentada como prova da infinita e imortal esperança de Deus no homem, diante de cuja liberdade da vontade humana estão fechados todos aqueles que não lhe abriram os movimentos do próprio coração: 
Então, quando saí da tarimba e olhei ao redor, lembro-me de sentir subitamente que podia olhar para aqueles infelizes de uma forma completamente diferente, e que, de repente, como que por um milagre, todo o ódio e raiva tinham desaparecido do meu coração. Caminhei, olhando com atenção no rosto daqueles que encontrava. Esse mujique difamado e de cabeça raspada, com marcas no rosto, bêbado, bradando sua rouca e embriagada canção, pode ser aquele mesmo Marei: com efeito, eu não consigo perscrutar seu coração. ${ }^{23}$

Dessa forma, a páscoa nas galés se torna para Dostoiévski o momento de seu nascimento como artista, de abertura de seus "olhos de artista", capazes de ver o homem como beleza (Maria, que na Anunciação permite que Deus fique com o homem, ou seja, revela e realiza a possibilidade de transfiguração de qualquer homem em Homem de Deus) encerrada na imagem humana, que pode se tornar seu caixão coberto, como a terra, a camada de imundície, mas a imundície pode se converter em terra fértil, e a imagem humana pode se tornar o local de ressurreição da beleza. Então, é possível transfigurar-se a si mesmo e aos outros, como se tornou "vivo" o caixão do Senhor, "fonte de nossa ressureição" ${ }^{24}$.

\section{REFERÊNCIAS BIBLIOGRÁFICAS}

DOSTOIÉVSKI, F. M. "Dois suicídios". In: Contos reunidos. São Paulo: Editora 34, 2017. Tradução de Priscila Marques.

"Mujique Marei". In: Clássicos do conto russo. São Paulo: Editora 34, 2015. Tradução de Priscila Marques. Os irmãos Karamázov. São Paulo: Editora 34, 2008. Tradução de Paulo Bezerra.

. Pólnoe Sobránie Sotchiniéni v tridtsati tomakh. Leningrado: Naúka, 1978, vol. 18.

Pólnoe Sobránie Sotchiniéni $v$ tridtsati tomakh. Le-

${ }^{23}$ DOSTOIÉVSKI, 2015, p. 180.

${ }_{24}$ "Portador da vida, mais belo que o paraíso, realmente mais resplandecente do que qualquer palacete real, Cristo, Vosso túmulo é a fonte de nossa ressurreição". Hino de Páscoa da Igreja Ortodoxa. 
ningrado: Naúka, 1981, vol. 22.

KASSÁTKINA, T. O sagrado no cotidiano: a imagem dupla nas obras de F. M. Dostoiévski. Moscou: IMLI-RAN, 2015. Disponível em: <http://biblio.imli.ru/index.php/teor-litr/597-svyashchennoe-v-povsednevnom-dvusostavnyj-obraz-v-proizvedeniyakh-f-m-dostoevskogo> VETLÓVSKAIA, V. E. "Diário de um escritor" de 1876: sobre "Mujique Marei". In: Dostoiévski i mirováia kultura. Filologuítcheski jurnal. Moscou: IMLI-RAN, 2018, $\mathrm{n}^{\circ} 1$.

Tradução de Priscila Marques²5

${ }_{25}$ Priscila Nascimento Marques é tradutora, mestre e doutora pelo Programa de Pós-Graduação em Literatura e Cultura Russa da Faculdade de Filosofia, Letras e Ciências Humanas da Universidade de São Paulo, onde atualmente realiza estágio de pós-doutoramento (bolsa Fapesp, processo 2015/17830 -1). E-mail: priscilanm@gmail.com 